\title{
A Study on Social Enterprise Policy Landscape in Bangladesh
}

\author{
Md. Farhan Shahriar ${ }^{1}$, Md. Mamun Habib, $\mathrm{PhD}^{2}$ \\ 1 Private Sector Development Specialist, USAID Feed the Future Bangladesh Trade Activity, International \\ Development Group LLC, Dhaka, Bangladesh, E-mail: shahriarmdfarhan@gmail.com \\ 2 Graduate School of Business, Universiti Tun Abdul Razak (UNIRAZAK), Kuala Lumpur, Malaysia, E-mail: \\ mamunhabib@unirazak.edu.my
}

Corresponding Author: Md. Farhan Shahriar

Received: December 22, 2021

Accepted: January 10, 2022

Online Published: January 17, 2022

doi:10.11114/bms.v7i4.5450

URL: https://doi.org/10.11114/bms.v7i4.5450

\begin{abstract}
The purpose of the study is to highlight the policy landscape of the social enterprise which is not spoken in any of the present policies and laws of Bangladesh. This study reviews the existing policies and regulatory affairs related to social enterprise formation and operations in Bangladesh. This study also focuses on the analysis of literature that described the national, regional and international good practices on social enterprise. This study tries to find out the past, present and future insight and findings of social enterprises policy implications in Bangladesh. This study finds the breadth and ranges of the policy approaches that the government has implemented for social enterprise development and policy priority for Bangladesh. Because at present in Bangladesh a social enterprise can establish and operate under different laws as there is no specific policy to register and operate the social enterprise in Bangladesh, so it's confusing for the social entrepreneur to register under appropriate law that will benefit them in the future. This study is based on the detailed assessment accessible in online literature and current data on social enterprise in Bangladesh, analysis of the existing policies and regulatory affairs on social enterprise in Bangladesh. This study is dependent on the qualitative approach along with the unstructured interviews with the industry experts. This paper presents a solid case study regarding the existing policy and regulatory implications of social enterprise formation and operations in Bangladesh.
\end{abstract}

Keywords: Social Enterprise, Policy Landscape, Policy Framework, Sustainable Development Goals, Bangladesh

\section{Introduction}

There are many explanations of social enterprises and the related concepts in worldwide and Bangladesh. Professor Mohammed Yunus said, "Social business is a cause-driven business. In a social business, the investors/owners can gradually recoup the money invested, but cannot take any dividend beyond that point" (Social Business, 2007). Sir Fazle Hasan Abed, founder of BRAC developed a mixed model of social enterprises and at present BRAC runs this model of social enterprises that the mixture of traditional development, health, nutrition, BoP last-mile supply chain, microfinance and education programs with additionally profitable business activities that ensures the double bottom line like BRAC Bank and bKash model (Shuvra, 2019). Social Enterprise Mark CIC is the social enterprise accreditation authority in the UK which provides clear standards to assure the business model remains ethical, credible and commercial and this authority defined social enterprise as a business that plows its profits back into a strong social or environmental mission - i.e. trading to create benefits for people and planet (Social Enterprise Mark CIC, 2016).

Social enterprises are socially cause-driven businesses that tackle social and environmental issues through a market-driven business approach. The purpose of the investment in social enterprise is to achieve the unmet social needs through for-profit or non-profit operations. There are no personal benefits for the investors nevertheless, social enterprises create jobs and generate income like other for-profit businesses and use profits for sustainability and reinvestment to support their social mission. However, profits are not the primary concern for a social enterprise but revenue-earning still plays a crucial role in the sustainability of the enterprise and sustainable revenue differentiates a social enterprise from a traditional non-profit or a charity that relies on donors' funding in different forms such as donations or grants. Social enterprises dedicated to achieving the social mission where need social intervention such as providing healthcare, housing facilities, financial services, nutrition for malnourished children, safe drinking water, or last-mile distribution facilities for the pro-poor, poor and BoP consumers. All social enterprises usually adopt two 
main goals - profit generation and fulfill a basic unmet need or solve social, cultural, economic, or environmental outcomes outlined in the enterprise's mission. There is no defined or structured government nor nationally recognized definition for the social enterprise concept in Bangladesh. The study attempts to identify the policy and judicial context of social enterprises in Bangladesh based on studying prevailing social enterprise activities, looking at government legislation and policies. This study also tries to determine the latent forthcoming deviations to the policy that encourages social enterprises development in Bangladesh. This study also demonstrates instances from different countries, which have a strong social enterprise policy setup. Following are the snapshot of social enterprise, charity and commercial companies.

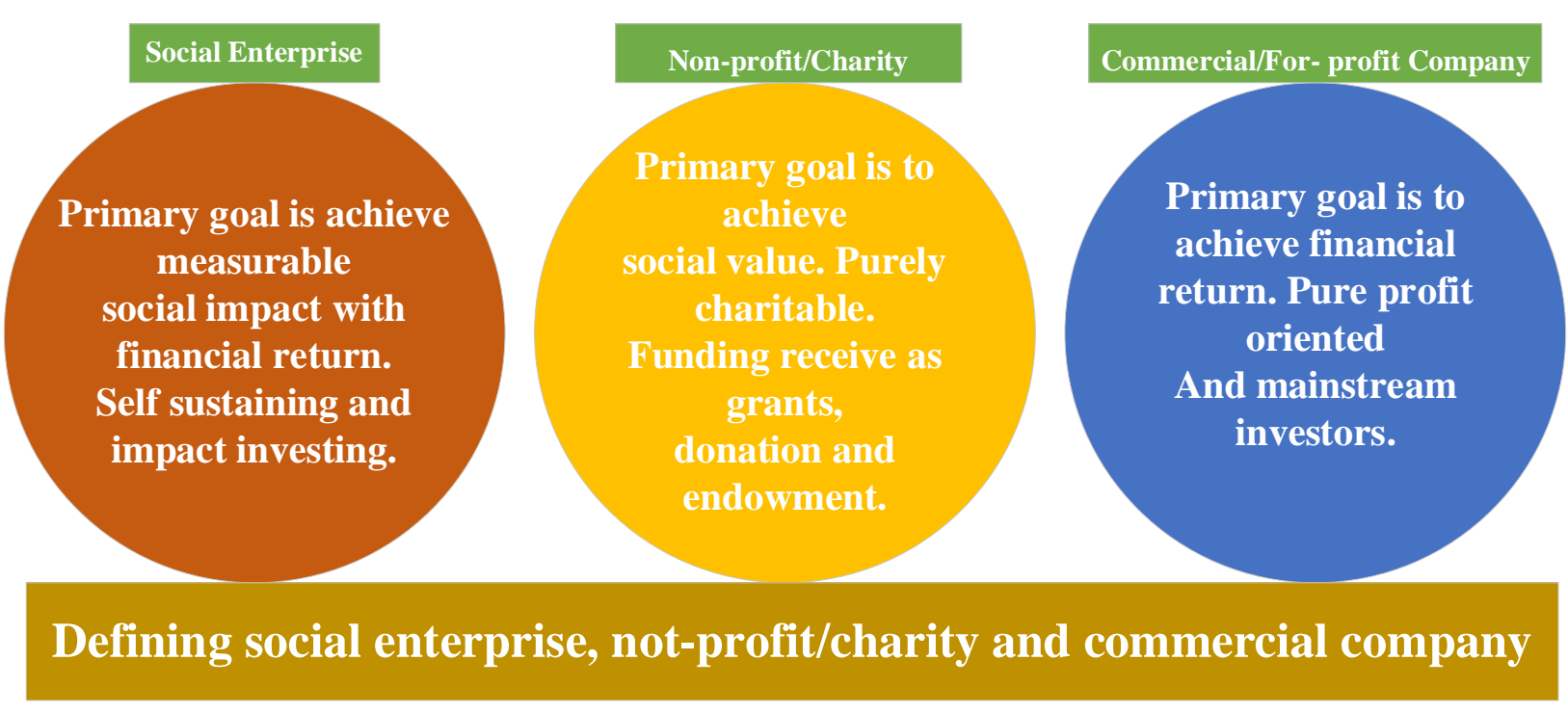

The objectives of establishing a social enterprise are following-

- A social enterprise is a business with social objectives that serve its mission;

- A social enterprise tries to overcome poverty and many other unmet problems of the society such as education, health, financial access, and poverty;

- Profit maximization is not the primary goal of a social enterprise rather creating the social impact on society;

- Social enterprises generate revenues for sustainability and spending on social development;

- Social enterprises create jobs and especially focus on high-risk communities.

There was no worldwide self-evident definition of social enterprise nor universally accepted alternative term for social enterprise. There are different definitions of social enterprise worldwide but the main theme is the same. British Council Bangladesh continually works on and published a series of reports on social enterprises in Bangladesh. "Social Enterprises Policy Landscape in Bangladesh" is one of them and this report perhaps facilitated Bangladesh to edge its social enterprise concept and definition where most of the stakeholders were uncertain. 
Table 1. Major distinctions between definitions recognized by Bangladesh stakeholders (Darko and Sultana, 2016)

\begin{tabular}{|c|c|c|c|}
\hline Definition & Use of Profits/ Surplus & Ownership & Business Model \\
\hline $\begin{array}{ll}\text { Yunus } & \text { Social } \\
\text { Business } & \end{array}$ & $\begin{array}{l}\text { Profit invested in the } \\
\text { expansion of the business or } \\
\text { can be used tsed to start } \\
\text { another social business. }\end{array}$ & $\begin{array}{l}\text { There is no } \\
\text { individual } \\
\text { ownership, no } \\
\text { dividends and no } \\
\text { shares issued to the } \\
\text { shareholders. The } \\
\text { company itself is } \\
\text { the owner. }\end{array}$ & $\begin{array}{l}\text { Profit-making business } \\
\text { model. }\end{array}$ \\
\hline $\begin{array}{l}\text { UK } \quad \text { Business, } \\
\text { Innovation and } \\
\text { Skills Department }\end{array}$ & $\begin{array}{l}\text { Mainly reinvested for the social } \\
\text { purpose or in the community } \\
\text { rather than driven by } \\
\text { shareholders need to capitalize } \\
\text { the profits. }\end{array}$ & $\begin{array}{l}\text { Not stated in the } \\
\text { model. }\end{array}$ & Not stated in the model. \\
\hline $\begin{array}{l}\text { Smith and Darko } \\
(2015)\end{array}$ & $\begin{array}{l}\text { Surplus profits are used for social } \\
\text { benefits. }\end{array}$ & $\begin{array}{l}\text { Not stated in the } \\
\text { model. }\end{array}$ & $\begin{array}{llr}\text { Operational } & \text { processes } & \text { adapt } \\
\text { commercial } & \text { orientation } & \text { like } \\
\text { sharing } & \text { profits } & \text { with } \\
\text { customers, } & \text { cross-subsidizing } \\
\text { some customers. }\end{array}$ \\
\hline Charity/NGO & $\begin{array}{l}\text { No profit gain from the } \\
\text { operation if any surplus remains } \\
\text { after the project, then need to } \\
\text { back the surplus to the donor. }\end{array}$ & $\begin{array}{l}\text { The elected governing } \\
\text { body and executive } \\
\text { board. }\end{array}$ & Non-profit model. \\
\hline $\begin{array}{l}\text { Inclusive } \\
\text { Business }\end{array}$ & Not stated in the model. & $\begin{array}{l}\text { Not stated in the } \\
\text { model. }\end{array}$ & $\begin{array}{l}\text { Profit-seeking model and } \\
\text { decisively trying to increase } \\
\text { social impact through } \\
\text { business operations. }\end{array}$ \\
\hline $\begin{array}{ll}\text { Corporate } & \text { Social } \\
\text { Responsibility } & \end{array}$ & $\begin{array}{l}\text { CSR is a portion of the profit } \\
\text { from commercial operations that } \\
\text { are allocated to the social good. }\end{array}$ & $\begin{array}{l}\text { The commercial } \\
\text { venture is the owner } \\
\text { and controls the CSR } \\
\text { expenditure. }\end{array}$ & $\begin{array}{l}\text { CSR amount provides as a } \\
\text { grant or donation for social } \\
\text { good. }\end{array}$ \\
\hline
\end{tabular}

These definitions demonstrate different aspects of social enterprise and social business that will help the readers to understand the major distinctions between definitions. But the main theme is the same that is social impact, profitability and sustainability.

\section{Literature Review}

There has been a remarkable growth in social enterprises in the last decade because social enterprise brings sustainable economic growth while fostering social change and innovation around the globe. Nonetheless in Bangladesh, the social enterprise sector has been gradually growing though there are two world-famous social enterprises established and operating in Bangladesh which are Grameen Bank and BRAC. Grameen Bank and BRAC dominate the social enterprise landscape and developed their successful approach. However, to channel the advantages and benefits of the 
social enterprise to the beneficiaries and the country's economy, Bangladesh needs a well-planned, short-term, long-term realistic and logical policy to incorporate the government, legislative bodies, private sectors and academia to create the infrastructural supports to establish, grow and expansion of social enterprises though at present it is absent in the country.

Bangladesh facing several challenges with the social and economic development of the country which can include the low social and economic status of women, ethnic and minority groups, drastic climate changes, food safety are the major problems and there are huge scopes of establishing and growing social enterprises within the country territory but only a small number of policy-related research exist in Bangladesh. The Bangladesh Enterprise Institute produced a report in 2010 that addressed poverty, social enterprise policies and their implications in Bangladesh (Bangladesh Social Enterprise Project - Bangladesh Enterprise Institute, n.d.). The British Council also produced another report on social enterprise in Bangladesh that briefly presents the social enterprise ecosystem and existing policy support and global good practices in the context of Bangladesh (Darko and Sultana, 2016). The British Council has also hosted three social enterprise dialogue events started from the year 2015 to 2017. Dalberg and GIIN (2015) produced an impact investment report which includes a chapter on Bangladesh that estimates the number of impact enterprises operating in Bangladesh by sector.

\section{Methodology}

This study developed the findings based on the detailed review of available online literature and existing information on social enterprise in Bangladesh, analysis of the existing policies and regulatory affairs on social enterprise in Bangladesh and analysis of literature that described the national, regional and international good practices on social enterprise. This study is dependent on the qualitative approach to understanding what social enterprise representatives think about the importance of the policy landscape for social enterprise in Bangladesh along with the unstructured interviews with the industry experts. This study is also dependent on both primary and secondary data. Mostly used available secondary information though expert opinion is considered as the primary data. The secondary data were collected from various sources like case studies, journals, conference papers, books, websites, annual and audit reports of some existing social enterprises in Bangladesh. Besides, unstructured interviews were taken from the representatives of the social enterprises that were considered as the primary data source for this study.

\section{Existing Policies \& Registration Laws}

Bangladesh has a worldwide reputation for social enterprise establishment and impact creation towards the country and its people. The flow of establishing the social enterprise in Bangladesh is slow though BRAC was established in 1972 and Grameen Bank in 1976. The majority of the social enterprises were established and started operating at least two decades later of BRAC and Grameen Bank that was quite unexpected due to country regulations and policies. There is no specific policy related to social enterprise in Bangladesh but some policies are helping this sector to establish and grow social enterprise in Bangladesh though these are not enough to encourage the establishment and operation of social enterprise in Bangladesh. A report produced by the British Council Bangladesh named "The state of social enterprise in Bangladesh, Ghana, India and Pakistan described the details policies with some degree of relevance to the social enterprise are given in Table 2. 
Table 2. Policies helping to establish social enterprises in Bangladesh (British Council Bangladesh, 2016)

\begin{tabular}{|c|c|c|c|}
\hline Policy Name & Agency Responsible & Date & Detail - relevance to social enterprise \\
\hline $\begin{array}{l}\text { Societies Registration Act, } \\
1860\end{array}$ & $\begin{array}{c}\text { Registrar of Joint Stock } \\
\text { Companies, Ministry of } \\
\text { Commerce }\end{array}$ & 1860 & \multirow{2}{*}{$\begin{array}{l}\text { The Companies Act sets out detailed criteria for } \\
\text { the non-profit organization, unlimited and } \\
\text { limited companies' registration but it does not } \\
\text { address any issue about social enterprise as this } \\
\text { act is too old to maintain today's world's } \\
\text { business. }\end{array}$} \\
\hline $\begin{array}{l}\text { Companies Act, } 1913 \\
\text { (Amended 1994) }\end{array}$ & Ministry of Commerce & 1994 & \\
\hline Trust Act, 1882 & Registrar of Trusts & 1882 & Not specified. \\
\hline $\begin{array}{l}\text { Voluntary Social Welfare } \\
\text { Agencies Ordinance, } 1961\end{array}$ & $\begin{array}{c}\text { Department of Social } \\
\text { Welfare }\end{array}$ & 1961 & Not specified. \\
\hline NGO Law & $\begin{array}{l}\text { Registrar of } \\
\text { Companies }\end{array}$ & N/A & $\begin{array}{l}\text { This existing legislation permits for NGO } \mathrm{AB} \\
\text { registration for receiving foreign donations but not } \\
\text { the authority to register social enterprise. }\end{array}$ \\
\hline $\begin{array}{l}\text { Foreign Donations } \\
\text { Regulation Act, } 2014\end{array}$ & NGO Affairs Bureau & 2014 & $\begin{array}{l}\text { This Act sets out criteria for receipt of foreign } \\
\text { funding for NGOs, including permission from } \\
\text { the NGO Affairs Bureau. }\end{array}$ \\
\hline $\begin{array}{l}\text { Microfinance Regulatory } \\
\text { Law, } 2006\end{array}$ & Ministry of Finance & 2006 & $\begin{array}{l}\text { Microfinance licensing and regulatory body. Set } \\
\text { standards microfinance but directly not mention } \\
\text { about anything social enterprise and its } \\
\text { operation. }\end{array}$ \\
\hline $\begin{array}{l}\text { Bangladesh Securities and } \\
\text { Exchange Commission } \\
\text { (Alternative Investment) } \\
\text { Rules, } 2015\end{array}$ & $\begin{array}{l}\text { Bangladesh Securities } \\
\text { and Exchange } \\
\text { Commission }\end{array}$ & 2015 & $\begin{array}{l}\text { Bangladesh Securities and Exchange } \\
\text { Commission legislation covers private equity } \\
\text { funds, venture capital funds and impact funds. } \\
\text { Though impact fund related to a social } \\
\text { enterprise but doesn't said define anything } \\
\text { about the registration of social enterprise. }\end{array}$ \\
\hline
\end{tabular}

Social enterprises in Bangladesh have no specific and single legal status based on the existing policies like NGO Law, Trust Act, Voluntary Social Welfare Agencies Ordinance. At present in the Company Law of 1994, there is no provision for social enterprise establishment and operation in Bangladesh. So social enterprises are registered under regular legal forms under the Company Act 1994 or other legislative laws existing in Bangladesh. At present, the legal forms of registrations are mentioned below under which social enterprises can choose to register and operate. 
Table 3. Legal arrangements of business registration in Bangladesh (British Council Bangladesh, 2016)

\begin{tabular}{|c|c|}
\hline Legal Form & Description \\
\hline Sole Proprietorship & $\begin{array}{l}\text { Single owner and small business registered through trade license in Bangladesh. } \\
\text { Don't need any other licenses to operate the business except tax identification } \\
\text { number and value-added tax number. A sole proprietorship is not a separate legal } \\
\text { entity, so; it is not distinct from the owner/proprietor. The owner bears the full risks } \\
\text { of the business. }\end{array}$ \\
\hline Partnership & $\begin{array}{l}\text { Two to twenty persons can be created the partnership business through voluntary } \\
\text { agreements for profit-making intentions. The partnership agreement was formed } \\
\text { under the provisions of the Partnership Act, } 1932 \text {. }\end{array}$ \\
\hline Private Limited Company & $\begin{array}{l}\text { Owners of the company bear all types of risks and debts. They also share profits } \\
\text { among themselves. The Private Limited Company is administered by the Companies } \\
\text { Act, } 1994 \text {. }\end{array}$ \\
\hline Society Act & $\begin{array}{l}\text { The Societies Registration Act describes those seven or more persons allied for any } \\
\text { good or charitable reasons, or like any such type of purpose can be registered under } \\
\text { the society act. }\end{array}$ \\
\hline Trust & $\begin{array}{l}\text { Trust is administered by the Trust Act, } 1882 \text {. Under the trust act profit cannot be } \\
\text { distributed as dividends. }\end{array}$ \\
\hline $\begin{array}{l}\text { Social Voluntary } \\
\text { Organization }\end{array}$ & $\begin{array}{l}\text { Social Voluntary Organization mainly works with women and children. It is } \\
\text { administered by the Voluntary Social Welfare Agencies of Bangladesh. }\end{array}$ \\
\hline NGO & $\begin{array}{l}\text { NGO registration is legally incorporated with NGO Affairs Bureau through } \\
\text { performing various processes and procedures. NGO registration allows the } \\
\text { organization to receive any foreign funds/donations. }\end{array}$ \\
\hline
\end{tabular}

Social enterprises in Bangladesh have the latent potentiality in Bangladesh to fulfill the United Nation's Sustainable Development Goals of 2030. Bangladesh government can be one of the pioneers in South-East Asia and the Asia Pacific regions for experimenting the social enterprise-friendly policies to support the establishment and development of social enterprise markets within the country.

The social enterprise policy must be a mix of specific legal forms for the enterprise registration process and operations process, business incubation, funds/ grants support, seed investment from the Bangladesh government, subsidy and income tax rebate to encourage more social enterprises established in the country. The policy and law can be facilitated the business and infrastructure support services to nurture the high potential and long-lasting social enterprises in Bangladesh. Finally, social enterprise policy should include higher education, training, seminars and webinars on social entrepreneurship, impact investment and social enterprise policy dialogue to develop the like-minded next generation of social entrepreneurs so that the objectives of developing more social enterprises will fulfill. Moreover, the ambition of policy will create an enabling environment for impact investing to the enterprises.

\section{Good Practices from the Regional Context}

Some countries in South-East Asia and the Asia Pacific regions are the pioneers of social enterprise policies and laws development. Several factors drive social enterprise policies around the region and the main thing is that the traditional business models are failed to minimize the gaps of income inequality among the people. Despite the establishment and operations of social enterprises, some countries have done more than that through strengthening the policy innovations that enable social enterprises to nurture and create a greater impact within the region. Social enterprises are the potential hub of the invention to achieve the Sustainable Development Goals 2030. 
According to the policy approaches to scaling social enterprise and impact investment in Asia and the Pacific (2017, The Republic of Korea of North-East Asia developed the Social Enterprise Promotion Act in 2007 to strengthen the social enterprises' establishments and operations within the regions. Social Enterprise Promotion Act served new social enterprises with management consulting services, technical assistance for business model canvassing, business model and plan formation. This country provides shared rentals services and reduced taxes facilities for the newly established social enterprises. The Metropolitan Government of Seoul opened a Social Economy Support Centre that entertainments as a business incubator for social enterprises. And the Social Economy Support Centre has resulted in a 353\% growth in the number of social enterprises in Seoul between 2012 and 2015.

Malaysia from South-East Asia developed a social enterprise blueprint 2015-2018 to establish a social enterprise environment within the country that draws an outline of social enterprise policy establishment, incubation and operations including social entrepreneurship in national education systems. Thailand also aggressively focuses on establishing the social enterprises' sector ecosystem in the country to ensure the double bottom line. its social enterprise sector. Thailand Government established the Thai Social Enterprise Office in 2010 and arranged many facilities and subsidies for the social entrepreneurs. Viet Nam aggressively thought about social enterprise policy formation and legislative guidance and revised enterprise law in 2014 and add the legal definition of social enterprise to inspire, provision and endorse the development of social enterprises. The Philippines and Indonesia are also in the process of establishing policies to promote social enterprise in their economies.

The Governments of India and Pakistan from South Asia have already taken measures to create an innovation ecosystem to support social enterprises. India's policy framework positively identifies the appearance of social enterprise as a social impact business model and courses are delivered by universities and academic institutions on social entrepreneurship and enterprises. To promote and support the vision 2025, The Government of Pakistan supports the objectives of innovation and enterprises that specifically mentioned the social enterprises' section in the policy paper and established a center for Social Entrepreneurship for incubation for social enterprises.

\section{Findings}

The main objective of this study is to understand the past, present and future insight and findings of social enterprises policy implications in Bangladesh so that this study can suggest some policy level recommendations to the concerned government agencies to initiate a social enterprise policy paper to the growth and expansion of social enterprises in Bangladesh though there are no policies explicitly governing social enterprises activities in Bangladesh. The findings of this study are mostly dependent on secondary data that are mentioned below.

a) Lack of Clear Identity- A social enterprise in Bangladesh can register in different forms and also operate under many legal entities like the sole proprietorship, partnership, company act, society act, trust and NGO act. Therefore, registering a social enterprise is confusing and cumbersome for a social entrepreneur in Bangladesh.

b) Fitting to the Legal Forms- Social entrepreneurs in Bangladesh facing troubles to fit the organizations into the current setup of nonprofit and for-profit legal forms and maybe some newer forms as the concept of "impact enterprise" is relatively new in Bangladesh; though the initial landscape was built by Muhammad Yunus, who introduced the idea of "social business".

c) Insufficient Social Enterprise Policy Support System- In Bangladesh, there are few examples of social enterprises policy engagement, beyond the British Council's work in this area as the British Council Bangladesh has three policy engagement events in 2014, 2015 and 2016 where almost 200 support organizations, government officials, social enterprise representatives, journalists and business representatives were attended. Except for those three events, it's hard to find any national events organized in Bangladesh to support social enterprise policy advocacy.

d) Inadequate Social Enterprise Education Support System- There is no initiative for social enterprise curriculum development processes for the social entrepreneurs in Bangladesh. In fact, the Bangladesh government doesn't have any plan to develop a curriculum for social entrepreneurs.

e) Constraint on Access to Finance, Tax Rate, Custom and Trade Regulations- Government's weak regulations limit the access to finance to the new social enterprise, unfriendly tax rates and processes/administration are cumbersome that create constraints for the social enterprise. 
f) Lack of Awareness and Promotion- There is no explicit focus on awareness building and mass campaign from Government on social enterprise activities and impact.

g) Government Stakeholders Perceptions- This study finds that clarity and awareness about social enterprise and financial sustainability of social enterprise are absent to most government stakeholders. Even people who understand the concept of social enterprise don't look at it positively because of various misunderstandings about social enterprises (Darko and Sultana, 2016).

h) Insufficient Business Incubation Support from Government- Priority initiatives from the government to support the social enterprise incubation ecosystem is not sufficient. Moreover, social innovations and implementation are not encouraged within the business enabling environment and private sector development approaches and the whole social business ecosystem in Bangladesh are not working properly like the education and training, access to finance, research and development, working capital, and access to the market.

\section{Conclusion}

The objective of this study is to identify and explore the past and present policy and legislative context for social enterprise activity in Bangladesh by reviewing existing laws and initiatives of the government. This study tries to identify the government initiatives that encourage social enterprise development and expansion in Bangladesh. This study also explores some good practices from the regional context from South Asia, South East Asia and North-East Asia that have already a well-established social enterprise policy ecosystem. The good practices highlight the depth and breadth of the policy approaches that those economies have already implemented to the growth of the social enterprise. Though at present, there is no social enterprise-specific policy framework or government programs in Bangladesh and no explicit mention of social enterprise in strategy and policy. However, some other policies and acts indirectly contribute to social enterprise sector development though those are not enough to the harmonized growth of this sector.

\subsection{Recommendations}

The government of Bangladesh can support establishing social enterprise model excellence and support centers in all the divisions that support the potential and existing social entrepreneurs and enterprise regarding registration and operations. Because many social enterprises are very lean and need support from outside providers in areas such as legal, marketing, management consulting, and finance. This model excellence and support centers can provide support with an array of business development services and facilities. And some policy-level recommendations are following.

a) Consensus on Social Enterprise Definition- Conventional businesses play a key role in the value creation and economic development of Bangladesh and it should not be crowded out by the social enterprise. Lack of consensus on the definition of social enterprise means that much time could be wasted by the Government. So, the government should introduce and enforce a collective definition of social enterprise through law and policy.

b) Social Enterprise Policy Paper Development- Bangladesh government should take the initiatives to arrange a public-private dialogue platform to facilitate structured and constructive dialogues between the public and private associations to start the drafting of social enterprise policy.

c) Guideline/toolkit for Social Enterprise Registration- Registering social enterprise is confusing and cumbersome for a social entrepreneur in Bangladesh. It's important to develop a policy and guideline for social entrepreneurs to guide them through the legal and technical process of establishing a social enterprise so that they can understand the legal options and procedures, accurate and sufficient paperwork to establish a social enterprise in Bangladesh.

d) Tax Holiday, Friendly Policies and Regulations- This study paper recommends that the Government should introduce specific tax holidays or provision separate tax laws for social enterprises.

e) Consider Present Company Act- Government should consider some changes in current company law to provide separate and distinct provisions for social enterprises whether it can be for-profit or not-for-profit.

f) Social Enterprise Curriculum Development- Curriculum development on social entrepreneurship and enterprise and implementation at secondary to tertiary level education and training institutions. 
g) Awareness Building and Mass Promotion- Awareness building events and mass campaigns can grow the interest amongst individuals and organizations to clear the concept and establish more social enterprises in Bangladesh.

\subsection{Further Scope of the Research}

To understand the further policy-level initiatives and opportunities in the social enterprise ecosystem in Bangladesh, this study proposes some areas for further research. First, exploring the potential role of the existing social enterprise at the policy level advocacy with the government agencies. Second, the number of public-private policy-level dialogues held within the last five years. Third, the potential role of the Government agencies contributed to the growth and expansion of the social enterprise sector in Bangladesh. Finally, initiatives were taken to establish the social enterprise incubation support system.

\section{References}

Bangladesh Social Enterprise Project - Bangladesh Enterprise Institute. Retrieved 7 January 2022, from https:/www.yumpu.com/en/document/read/35000680/bangladesh-social-enterprise-project-bangladesh-enterprise-i nstitute

British Council Bangladesh (2016), The state of social enterprise in Bangladesh, Ghana, India and Pakistan(pp.5); $\begin{array}{llll}\text { Retrieved } & 7 & \text { January } & 2022,\end{array}$ https://www.britishcouncil.org.bd/sites/default/files/the_state_of_social_enterprise_in_bangladesh.pdf

British Council Bangladesh (2016). The state of social enterprise in Bangladesh, Ghana, India and Pakistan $\begin{array}{lllll}\text { [pp.13]. Retrieved } & 7 & \text { January } & \text { 2022, from }\end{array}$ https://www.britishcouncil.org.bd/sites/default/files/the_state_of_social_enterprise_in_bangladesh.pdf.

Darko Emily and Sultana Mirza Manbira (2016), SOCIAL ENTERPRISE POLICY LANDSCAPE IN BANGLADESH. [online] [pp.11]. Retrieved 7 January https://www.britishcouncil.org.bd/sites/default/files/social_enterprise_policy_landscape_in_bangladesh_vf.pdf

Darko Emily and Sultana Mirza Manbira (2016), SOCIAL ENTERPRISE POLICY LANDSCAPE IN BANGLADESH. [online] [pp.11]. Retrieved 7 January https://www.britishcouncil.org.bd/sites/default/files/social_enterprise_policy_landscape_in_bangladesh_vf.pdf

Darko Emily and Sultana Mirza Manbira (2016), SOCIAL ENTERPRISE POLICY LANDSCAPE IN BANGLADESH. [online] [pp.29]. $\quad$ Retrieved $7 \quad$ January $2022, \quad$ from: https://www.britishcouncil.org.bd/sites/default/files/social_enterprise_policy_landscape_in_bangladesh_vf.pdf.

Policy approaches to scaling social enterprise and impact investment in Asia and the Pacific. (n.d.). [online] [pp.4]. $\begin{array}{llll}\text { Retrieved } & 7 & \text { January } & 2022,\end{array}$ https://www.unescap.org/sites/default/d8files/event-documents/EESCAPFSD\%284\%29INF5.

Shuvra (2019). BRAC: Creating opportunities for people to realize potential. [online] Brac.net. Retrieved 7 January 2022 , from: http://www.brac.net/.

Social Business, $2007 \quad$ [online]; Retrieved $7 \quad$ January $\quad 2022, \quad$ from: https://www.muhammadyunus.org/post/2113/social-business

Social Enterprise Mark CIC. (2016); Round table on new courses for the social enterprise sector. [online] Retrieved 7 January 2022: https://www.socialenterprisemark.org.uk/what-is-social-enterprise/

The Global Impact Investing Network (GIIN) and Dalberg Global Development Advisors (2015); The landscape for impact investing in South Asia. Retrieved 7 January 2022, from: https://thegiin.org/research/publication/the-landscape-for-impact-investing-in-south-asia

\section{Copyrights}

Copyright for this article is retained by the author(s), with first publication rights granted to the journal.

This is an open-access article distributed under the terms and conditions of the Creative Commons Attribution license which permits unrestricted use, distribution, and reproduction in any medium, provided the original work is properly cited. 